WILLIAM L. MATHES

\title{
Russian Collections in Libraries and Archives of Warsaw
}

The purpose of this article is to provide a survey of Russian-language holdings available in Warsaw. It is designed as a guide for those interested in materials on Polish-Russian relations or Russian history and culture not available in the West and for those who have no immediate prospect of doing research in the Soviet Union. Broader contacts between Poland and the United States and possible exchanges between American and Polish institutions of higher education have added Warsaw to the list of European cities, such as Helsinki, in which research on selected aspects of Russian culture may be profitably conducted. The scholar who visits Warsaw on an exchange may anticipate prompt and courteous attention to his research requests. In Warsaw foreign scholars use the same reading rooms and reference facilities as the Poles. Letters sent in advance and describing the proposed research are appreciated, for they alert the appropriate archivists and librarians to the likely needs of the guest scholar. ${ }^{1}$

The research materials in Warsaw are limited to those items which survived World War II or which were acquired after 1945. The Warsaw archives and libraries suffered enormous losses during the war, from which general destruction the Russian holdings were not exempt. According to one estimate the archives in Warsaw lost 90 percent of their holdings, or 4,700,000 units, most of them destroyed by the Germans after the Warsaw Uprising of 1944. Several of Warsaw's libraries were burned by the Germans between September 1944 and January 1945, with an estimated loss of 1,280,000 library

1. A valuable handbook containing the names of Polish research institutions, archives, schools, museums, libraries, and their chief personnel is Informator Nauki Polskiej, 1972 (Warsaw: Państwowe Wydawnictwo Naukowe, 1972). There is an English translation of an earlier edition of this work, published for the National Science Foundation on the order of Centralny Instytut Informacji Naukowo-Technicznej Ekonomicznej: Polish Research Guide, 1964 (Warsaw: PWN, 1963).

The author wishes to acknowledge support received under HEW Group Projects Abroad, during a six-week tour in the winter of 1972-73, an exchange of faculty members between Warsaw's Szkoła Główna Planowania i Statystyki (Central School of Planning and Statistics) and Seton Hall University. 
units. ${ }^{2}$ After the war the slow task began of rebuilding shattered collections, of filling in gaps where possible, and of reassembling books and folios which had been dispersed by the Germans, hidden by the Poles, or relocated in buildings which had escaped destruction. The figures for the present holdings attest to the persistence and skill of the Polish people in effecting this recovery.

\section{Warsaw Libraries}

The information given in this article and in the accompanying table is based, unless otherwise indicated, on interviews with directors of libraries or reference librarians and on their responses to a questionnaire regarding the size of each collection, of its major components (for example, books, periodicals, and microfilms), and of the Russian-language holdings within the collection. Each respondent was asked to state the major area in which the Russian collection is strongest and to indicate the relative strength of the collection according to specified chronological periods. Other data collected include information on the special features of the Russian collection, the method by which it is indexed, and the accessibility to it.

Russian books, periodicals, and other research materials are not generally listed in separate card catalogues, and where separate sheaf catalogues of such holdings do exist, they are seldom complete. The figures given for the Russian holdings, where rounded to thousands, are the estimates of the librarians who responded to the questionnaire. Not all Warsaw libraries are included in this survey: some because they have insignificant Russian holdings, ${ }^{3}$ others because their collections are not generally open to foreign visitors, ${ }^{4}$ and still others because they did not respond to the questionnaire. ${ }^{5}$

The data given here concern the current status of the Russian collections in the following Warsaw libraries: (1) National Library (Biblioteka Narodowa), Hankiewicza 1, (2) Library of the University of Warsaw (Biblioteka Uniwersytecka w Warszawie), Krakowskie Przedmieście 26/28 and 32, (3) Municipal Public Library of the Capital City of Warsaw (Biblioteka Publiczna m. st. Warszawy), Koszykowa 26, (4) Library of the Central School of Planning and Statistics (Biblioteka Szkoły Głównej Planowania i Statystyki), Radowiecka 22, Blok B, (5) Central Library of Warsaw Polytechnical Institute

2. Adam Lewak, "The Archives and Libraries of Warsaw During World War II, 1939-1945," Polish Review, 3, no. 2 (Spring 1962): 34-36.

3. For example, Biblioteka Państwowej Wyższej Szkoly Teatralnej im. A. Zelwerowicza (Library of the Alexander Zelwerowicz State Theatrical Higher School).

4. Biblioteka Wojskowej Akademji Politycznej (Library of the Military Academy of Political Science).

5. Most notably, the two chief medical libraries, Główna Biblioteka Lekarska (Central Medical Library) and Biblioteka Akademji Medycznej w Warszawie (Library of the Academy of Medicine in Warsaw). 
(Biblioteka Główna Politechniki Warszawskiej), Plac Jedności Robotniczej 1, (6) Central Library of the Academy of Agriculture (Biblioteka Główna Akademii Rolnicza), Rakowiecka 26/30, (7) Library of the Polish Academy of Sciences in Warsaw (Biblioteka PAN w Warszawie), Pałac Kultury i Nauki, (8) Library of the Institute of Art of the Polish Academy of Sciences (Biblioteka Instytutu Sztuki PAN), Długa 26/28, and (9) Library of the Academy of Fine Arts in Warsaw (Biblioteka Akademii Sztuk Pięknych w Warszawie), Krakowskie Przedmieście 5. ${ }^{8}$

The National Library (BN), whose administrative offices and major collection are located on Hankiewicza Street in the Ochota section of Warsaw, is the central state library of Poland. It is a national depository library which since 1927 has received an obligatory copy of all publications issued in Poland. It is not a lending library, and its materials may be used in its own reading rooms or in other libraries by special arrangements only. In general, the collection is catalogued by author, since 1945 by author and subject, but no single catalogue covers the entire collection. Consequently, for publications issued before 1945 full bibliographical details are required in the majority of cases. The National Library also houses duplicate catalogues of all Polish libraries and puts out union catalogues of Polish and foreign periodicals and of old and foreign books. These catalogues are helpful in locating books and periodicals in other Polish libraries. The National Library's microfilm department and its special collections of manuscripts, rare books, music, maps, graphics, and iconography are located in the former Republic Palace at 5 Krasiński Square. ${ }^{7}$

The National Library endeavors specifically to build up a comprehensive collection of Russian Polonica-that is, books by Polish authors, books in Polish, or books concerning Poland-published in Russia and the Soviet Union. Its Russian collection is strongest in the humanities and the social sciences. Chronologically, it is made up of isolated Russian materials for the period 1765 to 1921, including approximately four hundred volumes in Russian

6. The author is indebted to several members of the staff of each of these institutions for information provided in this essay. $\mathrm{He}$ wishes in particular to thank the following persons, listed in the order of their institutional affiliations, as given above: (1) Ewa Suchodolska, (2) Hanna Zasada, (3) Stefan Durmaj and Andrzej Wesolowski, (4) Aleksandra Zabielska-Helle, (5) Grzegorz Bogdan, (6) Tadeusz Marszałek, (7) Janina Westermark, (8) Irena Chmielinska, and (9) E. Szańkowska. He wishes also to thank the Department of Economic History at SGPiS for assistance in arranging the interviews, especially Prorector Irena Kostrowicka and Professors Janusz Kaliński and Teresa Małecka.

7. For additional information regarding the general collection see Vitol'd Stankevich, "Glavnye nauchnye biblioteki v Pol'she kak laboratorii istoricheskikh issledovanii," in Istoricheskaia nanka $v$ narodnoi Pol'she $v$ 1945-69 gg.: Spravochnik . . . (Warsaw: PWN, 1970), pp. 181-83; Zofia Zydanowicz, The National Library Guide (Warsaw: Drukarnia Biblioteki Narodowej, 1966); and Biblioteka Narodowa: Informator dla czytelnikbzw (Warsaw: Biblioteka Narodowa, 1963). 
Total Holdings and Russian Holdings in Warsaw Libraries (January 1973)

\begin{tabular}{|c|c|c|c|c|c|c|c|c|}
\hline \multirow[b]{2}{*}{ Library } & \multicolumn{4}{|c|}{ Total Holdings (all languages) } & \multicolumn{4}{|c|}{ Russian-Language Holdings } \\
\hline & $\begin{array}{l}\text { Books } \\
\text { (total } \\
\text { printed, } \\
\text { bound } \\
\text { vols.) }\end{array}$ & $\begin{array}{l}\text { Books } \\
\text { (pre- } \\
1800 \\
\text { vols. } \\
\text { only) }\end{array}$ & $\begin{array}{l}\text { Period- } \\
\text { icals } \\
\text { (vols.) }\end{array}$ & $\begin{array}{l}\text { Manu- } \\
\text { scripts } \\
\text { (units) }\end{array}$ & $\begin{array}{l}\text { Books } \\
\text { (total } \\
\text { printed, } \\
\text { bound } \\
\text { vols.) }\end{array}$ & $\begin{array}{l}\text { Books } \\
\text { (pre- } \\
1800 \\
\text { vols. } \\
\text { only) }\end{array}$ & $\begin{array}{l}\text { Period- } \\
\text { icals } \\
\text { (vols.) }\end{array}$ & $\begin{array}{l}\text { Manu- } \\
\text { scripts } \\
\text { (units) }\end{array}$ \\
\hline National Library (BN) & $1,144,629$ & 100,130 & 352,623 & 10,369 & 50,000 & $400 \mathrm{c}$ & $2,500^{\mathrm{d}}$ & $527 \mathrm{e}$ \\
\hline $\begin{array}{l}\text { Library of the University of } \\
\text { Warsaw (BUwW) }\end{array}$ & $1,066,401$ & 120,702 & 450,371 & 3,303 & 250,000 & 715 & $4,200^{d}$ & $15^{\circ}$ \\
\hline $\begin{array}{l}\text { Municipal Public Library of } \\
\text { Warsaw (BPmsW) }\end{array}$ & 723,391 & 11,317 & 102,999 & 3,169 & 40,000 & - & 6,000 & 0 \\
\hline $\begin{array}{l}\text { Library of the Central School of } \\
\text { Planning and Statistics (BSGPiS) }\end{array}$ & 319,179 & 1,861 & 114,140 & 23,451 & $65,000^{\mathrm{b}}$ & 0 & - b & 0 \\
\hline $\begin{array}{l}\text { Central Library of Warsaw Poly- } \\
\text { technical Institute (BGPW) }\end{array}$ & 200,000 & $\rightarrow$ & 50,000 & - & 20,000 & 0 & 5,000 & - \\
\hline $\begin{array}{l}\text { Central Library of the Academy } \\
\text { of Agriculture (BGAR) }\end{array}$ & 117,260 & 108 & 42,291 & 11,190 & 25,000 & 0 & 12,000 & 0 \\
\hline $\begin{array}{l}\text { Library of the Polish Academy } \\
\text { of Sciences (BPANwW) }\end{array}$ & 79,257 & - & 76,876 & 0 & 11,900 & 0 & 7,700 & 0 \\
\hline $\begin{array}{l}\text { Library of the Institute of Art } \\
\text { of the Polish Academy of } \\
\text { Sciences (BIS PAN) }\end{array}$ & 70,000 & 200 & 25,000 & 1,291 & 7,000 & 0 & 1,129 & 0 \\
\hline $\begin{array}{l}\text { Library of the Academy of Fine } \\
\text { Arts in Warsaw (BASPwW) }\end{array}$ & 14,843 & 57 & 4,399 & 0 & 605 & 10 & 211 & 0 \\
\hline
\end{tabular}

a Data not available or not forthcoming. b Includes books and periodicals. c Old Church Slavonic or Russian. a Number of titles. The number of volumes is much larger. 
published before 1800 , insignificant Russian holdings for the period 1921-45, but a strong, representative set of Russian titles for the postwar period.

The Library of the University of Warsaw (BUwW) suffered serious damage to its central building in 1944, and 95 percent of its manuscripts, previously ordered removed to the Krasiński Library by the German authorities, perished during the deliberate destruction of the latter building in October 1944. ${ }^{8}$ Despite those wartime losses BUwW still possesses the largest university library collection in Poland. The collection long ago outgrew the capacity of the central building erected in 1894. Today the special collections, the reading room for current periodicals, the theses library, the microfilm section, and the administrative offices are located in the nearby Tyszkiewicz (Potocki) Palace at 32 Krakowskie Przedmieście. In addition to these facilities the University Library oversees about sixty-five faculty, institute, and departmental libraries. The main library houses the general alphabetical catalogue (by author), the general subject catalogue (complete for newer acquisitions only), a separate periodicals catalogue (by titles), and the catalogues for books and periodicals in the seminar libraries.

The Russian holdings are about 20 percent of the total collection of the Library of the University of Warsaw. The Library is one of the richest in the world, outside the Soviet Union, in nineteenth-century Russian works. It has 715 volumes in Russian published before 1800 and some isolated Russian materials for the period from 1800 to 1869 . However, the real strength of the Russian collection dates from 1869, when the Warsaw Central School was transformed into a Russian imperial university, to 1915 , when that university was evacuated to Rostov-on-the-Don. In 1893 the collection was enriched by a large bequest from Arkadii Tolochanov, a Russian official in the Kingdom of Poland. The Tolochanov collection consisted of 7,473 titles (in 15,362 bound volumes) and 190 periodicals. ${ }^{9}$ As a consequence of that and other donations the University Library is rich in Russian legal documents, statistical reports, and civil-service records, especially those dealing with the Polish sector of the empire. It also includes many publications dealing with Russian revolutionary movements between 1870 and 1915, valuable Russian books published abroad, and a collection of about eighty Ukrainian-language publications dating from the second half of the nineteenth century. For the period 1921-45 the Library's collection of Russian materials is spotty, and for the period since 1945 it is large but incomplete. In general, the Russian collection is strongest in the fields of history, literature, law, medicine, and natural sciences.

8. Lewak, "The Archives and Libraries of Warsaw," pp. 16, 19, 23, 31-32; Wanda Stummer, "The University of Warsaw Library," in Aleksander Gieysztor, ed., The University of Warsaw (Warsaw: Warsaw University Press, 1967), pp. 65-66.

9. Alexandre Thikian, "Note sur la Bibliothèque Universitaire de Varsovie et ses fonds russes," Cahiers du monde russe et soviétique, 8, no. 2 (1967): 333: 
The Library of the University of Warsaw has about 4,200 Russian titles in its periodicals collection. Again, the nineteenth century is well represented. A printed catalogue of Russian periodicals is now in preparation..$^{10}$ There are about fifteen storage units of Russian manuscript materials in the Library, each unit comprising many letters and papers. The manuscript collection includes letters, notes, and biographical documents written by professors and students of the Russian Imperial University at Warsaw (1869-1915), papers of Russians living in the Polish territories under Russia's control, and a unit of Belorussian folklore compiled at the turn of the century by the Polish ethnographer M. Federowski. From the 1920s and 1930s isolated Russian materials have survived, such as the letters of the Russian publicist Dmitrii Filosofov to the Polish novelist Maria Dąbrowska. The Russian manuscript materials are catalogued and indexed by author and by topic. ${ }^{11}$

The Kierbedź Public Library, now called the Municipal Public Library of the Capital City of Warsaw (BPmsW), also sustained heavy losses during the last war. In November 1944 several thousand volumes were moved from the Library as part of a planned evacuation. On January 15, 1945, the Germans set fire to the Library and thus destroyed the nearly 200,000 volumes in its stacks and a large part of its reference collection. ${ }^{12}$ Thanks to postwar donations and to the recovery of the books removed from the building before its destruction, the collection of the main library (excluding its branches) today consists of 826,000 bound volumes and periodicals, 3,169 manuscripts, and 8,394 units of cartographic materials. Of this collection about 46,000 volumes of books and periodicals are in Russian. The Russian collection is strongest in the humanities and for the period since 1945. However, BPmsW has some isolated Russian materials from earlier periods, though very few items published before 1800 . The general alphabetical catalogue includes the names of the authors and titles of all Russian items; a catalogue of the Russian periodicals collection is in preparation. The main branch of $\mathrm{BPmsW}$ has 5,000 Russian books in its lending library. A distinctive feature of the Library is the separate reading room for children, which contains books in many languages, including six hundred volumes in Russian.

The Library of the Central School of Planning and Statistics (BSGPiS) was created in 1906 to serve the needs of the faculty and students of what was then called the Higher Commercial Courses (renamed the Higher School of

10. Sixty-seven Russian periodicals are listed, along with publication data and the details of the Library's holdings, in a draft booklet entitled "Katalog Czasopism Rosyjskich Biblioteki Uniwersyteckiej w Warszawie," zeszyt próbny (Warsaw: Biblioteka Uniwersytecka w Warszawie, 1972), 32 pages. This is an ongoing project.

11. Helena Kozerska and Wanda Stummer, Katalog rękopisów Biblioteki Unizuersyteckiej $w$ Warszazie, vol. 1 (Warsaw: BUwW, 1963). Volume 2 is in press.

12. Lewak, "The Archives and Libraries of Warsaw," p. 32. 
Conmerce in 1915 and the Central School of Commerce in 1933). After being housed in several temporary quarters, the growing collection of the school was moved in 1931 to a specially designed building at 6 Rakowiecka Street. Under the German occupation the collection was incorporated into the Deutsche Staatsbibliothek. As a result, the collection of the Library of the Central School of Commerce was one of the few to escape wartime destruction. In 1949 the Central School of Commerce and its Library were nationalized and assumed their current names. ${ }^{13}$

At the present time the Russian collection of 65,000 volumes constitutes 15 percent of the total holdings of books and periodicals in the Library of the Central School of Planning and Statistics. Because of the continuous growth of the general collection since 1906 and the relatively small loss of about 5 percent of its holdings during World War II, the Library has some valuable Russian materials from the mid-nineteenth century and a large Russian collection on economics and economic history from 1906 to 1939. For the period since 1945 the Russian collection in the social and economic sciences is rather complete. The areas of greatest strength are the history of economic thought, economic policy, statistics and demography, accounting and finance, sector economics, labor and social policy, and the history of workers' movements. The Library attaches particular importance to the acquisition of periodicals and of materials dealing with Polish-Russian economic relations. The entire collection, including the Russian materials, is catalogued by author, title, and subject.

The Central Library of Warsaw Polytechnical Institute (BGPW), located at Plac Jedności Robotniczej 1, was seriously damaged during the last war and lost about 20,000 library units. Today the Library houses approximately 250,000 volumes of books and periodicals, ${ }^{14}$ roughly 10 percent of which are in Russian. All branches of engineering and the related sciences are included in the general collection, and though the Russian holdings for the period before 1945 are few, postwar Soviet publications on engineering and industrial technology are well represented. The general collection of the Library is open to anyone interested in engineering. It is indexed by author and by topic, but there is no separate index for the Russian holdings.

One Warsaw library which was spared serious losses during World War II was the Central Library of the Academy of Agriculture (BGAR), which until 1973 was called the Central School of Rural Economy. The collection -strongest in the disciplines of agriculture, timber management and tech-

13. Stefan Wrzosek and Aleksandra Zabielska-Helle, Guidebook (Warsaw: Library of the Central School of Planning and Statistics, 1972), pp. 7-10. titles.

14. Acquisitions for 1973 are expected to total 2,781 volumes, including 268 Russian 
nology, and horticulture-includes about 12,000 volumes of periodicals and 25,000 books in Russian. The Russian holdings include 5,000 volumes dating from 1855-1921, some 200 items from 1921-39, and about 6,800 Russian books published since 1945 . The Russian materials are indexed by author, title, and topic.

Poland's Academy of Sciences has many regional and departmental divisions, and the Library of the Academy is divided along similar lines. As an historian the author wishes to call special attention to the Department of the History of Polish-Soviet Relations of the Polish Academy of Sciences (Zakład Historii Stosunków Polsko-Radzieckich PAN) and to the Library of the Polish Academy of Sciences in Warsaw (BPANwW), located respectively on the twentieth and sixth floors of the huge Palace of Culture and Science. The first, a center with a staff of twenty, is engaged in research on PolishSoviet relations from 1917 to the present. The Library of the Polish Academy of Sciences, a central reference research library, concentrates on acquiring materials on the development, achievements, and current status of the sciences. The collection of BPANwW consists of 79,257 books and 76,876 volumes of periodicals representing 7,314 titles, of which 1,275 are current publications. In addition the Library has 36 microfilm items and 706 microfiche units. Of this collection about 15 percent of the books and 10 percent of the bound periodicals are in Russian. There are 849 Russian titles in the periodicals collection, 90 of which are current. The Library has some isolated Russian items for the period from 1800 to 1945 , a large but incomplete collection of Russian holdings for the period from 1945 to 1962, and a strong, representative collection of Soviet books on the study of sciences published since 1962 (about 1,500 titles).

The Library of the Institute of Art of the Polish Academy of Sciences (BIS PAN), located near the former Republic Palace at 26/28 Dluga Street, houses a substantial collection of Polish and foreign publications dealing with the plastic arts, the theater, music, and film, and with the related biographical, reference, and memoir literature. The Russian-language portion of the collection is strongest in the area of art history. The Library contains 70,000 books, 25,000 volumes of periodicals, 1,291 manuscripts, and 1,431 microfilm units. Roughly 10 percent of the book collection is in Russian. In addition the Library has 1,129 volumes of periodicals in Russian (104 separate titles). The author and subject catalogues are sheaf catalogues. Where applicable, each topic within the subject catalogue is subdivided into chronological periods.

Finally, there is the Library of the Academy of Fine Arts in Warsaw (BASPwW), located at $5 \mathrm{Krakowskie}$ Przedmieście, opposite the main entrance to Warsaw University. It has a small collection of Russian books and periodicals ( 816 items) dealing with the fine arts. The Russian materials are catalogued by author, subject, and partly by title. In addition the holdings are listed in three inventory volumes. 


\section{Warsaw Archives}

The Central Administration of State Archives (Naczelna Dyrekcja Archiwów Państwowych), located in Warsaw, has under its jurisdiction three central archives and seventeen provincial or voivodeship archives with eightyeight local archives, which in turn are classified as either area (terenowe) or district (powiatowe) archives. Three of these will be discussed here: (1) Central Archives of Ancient Records (Archiwum Glówne Akt Dawnych), Długa 7, (2) Archives of Modern Records (Archiwum Akt Nowych), Rakowiecka 22, Blok B, and (3) State Archives of the Capital City of Warsaw and of the Warsaw Province (Archiwum Państwowe $\mathrm{m}$. st. Warszawy $\mathrm{i}$ Województwo Warszawskiego), Krzywe Koło 7. The first two are central archives; the third houses the city and provincial records and has jurisdiction over seven local archives within the Warsaw Province.

The placement of the Polish state archives corresponds in principle to the historical administrative units of the country. The archival materials dealing with the organs of state authority and with the central institutions are housed in the Central Archives of Ancient Records and the Archives of Modern Records, with 1918, the year in which Poland regained her independence, being the dividing line between the two. Documents of the organs of authority of the province (voivodeship), area, and district are kept in the respective archives of those administrative units, but they are combined where separate archives do not exist for each administrative subdivision. ${ }^{15}$

There is no overall inventory of Russian-language holdings in the Warsaw archives, and the following observations do not purport to be a substitute for such an inventory. However, some general remarks may be helpful to anyone interested in working with Russian-language documents in Warsaw.

First, it will be recalled that most administrative and legal documents of the Kingdom of Poland, created in 1815, were written in Polish prior to the Uprising of 1863-64. After the revolt was put down, the provinces which had made up the kingdom were incorporated into the Russian Empire and Russian was used exclusively in all offices of the general and local government. Consequently, the bulk of surviving Russian-language documents generated in Poland date from the mid-1860s to World War I. Some of the Russian documents were evacuated from Poland in 1915, but many of these were restored to Poland after the Treaty of Riga (1921), only to perish in 1944-45. During the past twenty years the Soviet Union has returned to Poland additional Russian-language materials for the period 1866-1917. Duplicates and microfilm copies of other documents have been donated also by other countries. Moreover, the collection was greatly enlarged by the postwar nationalization

15. The names, locations, and brief descriptions of the holdings of the existing regional archives are given in Informator Natki Polskiej, 1972, pp. 269-76. 
of the records (primarily in Polish) of the Ostrowski, Potocki, Radziwill, and other families. Nevertheless, it must be stressed that Poland lost vast amounts of archival resources in the course of its stormy history.

For the historian interested in just what Russian-language documents in the Warsaw archives may have survived from the nineteenth century, a valuable source of information is the periodical Archeion, an organ of the Central Administration of State Archives. ${ }^{16}$ It is published two or three times a year and includes articles (with summaries in English, French, and Russian) describing, sometimes with inventories and call numbers (sygnatury), the Russian-language materials returned to Warsaw by the Soviet Union. A few of these are cited below. Other continuing publications of NDAP, issued at irregular intervals, are Teki Archiwalne (Archival Files) and Zródta Historyczne (Historical Sources).

Of course the oldest and most valuable documents preserved in the Central Archives of Ancient Records (AGAD) predate the era of Russian influence by centuries. One such document dates from 1150, roughly from the midpoint of the Piast dynasty. The most valuable part of the collection consists of the Crown Archives of Cracow and Warsaw, the Royal Public Register, and documents pertaining to diets, legations, and crown and local courts. The collection also contains isolated documents for the periods of the Jagellonian dynasty, the elective kings, the partitions, through the liquidation of the Polish state in 1795. The archive itself was created by order of Duke Frederick August in September 1808 , but very little archival material has survived from the period of the Grand Duchy of Warsaw (1807-15). ${ }^{17}$

Of the documents which deal with the central organs of the Kingdom of Poland (1815-1917)-documents housed before World War II in the archive on Jezuicka Street-about 15 percent was saved by having been transferred during the German occupation, first to the Citadel and thence to Częstochowa. However, most of the records of diplomatic correspondence, of the Privy Chancery of the Governor (1832-63), of the Diet and the Senate (1807-30), and of the Warsaw Governors General perished during the German destruction of Warsaw. In 1945 about 4,000 fragments of the records of the State Secretariat for Polish Affairs (1815-66) and of the Imperial Chancery for Polish Affairs (1866-1917) were recovered from under the rubble of the building on Jezuicka Street. ${ }^{18}$ Of 2,000,000 archival units (groups of documents) in the

16. Archeion: Czasopismo naukowe, poswięcone sprawom archiwalnym ... (Warsaw: PWN), vol. 1- (1927-).

17. Irena Koberdova, "Gosudarstvennye arkhivy," in Istoricheskaia nauka v narodnoi Pol'she, pp. 146-52.

18. Kazimierz Konarski, "Zespół akt Sekretariatu Stanu Księstwa Warszawskiego, Królestwa Polskiego oraz Kancelarii J. C. Mości do Spraw Królestwa Polskiego (18071876)," Archeion, 44 (1966) : 128-29. 
prewar collections of the two archives for old records only 370,000 units were saved. The surviving documents have been combined in the present collection of the Central Archives on Długa Street.

A few specific examples may best illustrate the nature of the Russian documentation preserved in the Central Archives of Ancient Records. Approximately one-third of the 130,000 Russian-language documents produced by the Chancery of the Governor of Warsaw between 1866 and 1917 have survived to the present time. From the office of the Assistant to the Governor General of Warsaw for the period 1897-1917, 1,394 archival units survived both wars and were restored to Poland by the USSR in $1964 .^{19}$ Similarly, some of the records of the Russian district court in Warsaw (1866-1917), of courts subordinate to it, and of the office of the Warsaw district prosecutor were returned to Poland in $1964 .^{20}$ Surviving documents dealing with the activities of governmental agencies in Warsaw during the revolution of 1905-7 have been catalogued in published inventories. A number of these may be found in collections of Polish and Russian documents on the revolution. ${ }^{21}$ The same is true for materials dealing with the Polish sector of the Russian Empire during World War I and the revolutions of 1917.

The manuscript collection of the Archives of Modern Records (AAN) was especially hard-hit by the last war. On November 3,1944, the Germans burned $1,140,000$ archival units, or 95 percent of the collection. After the war the surviving documents-among them three hundred boxes of material removed from the city early in 1944-were reassembled and then supplemented by manuscripts recovered from German territory and by new materials appearing since the end of the war.

Today the restored Archives of Modern Records are located on the ground floor of the Library of the Central School of Planning and Statistics at 22B Rakowiecka Street, with the main entrance from 162 Niepodległości Avenue. The Archives contain surviving documents of the central authorities and the state administrative bodies beginning with 1918, namely the papers of the Sejm, the Highest Chamber of Control, the ministries, the president, and the attorney general. Some documents of the ministries of the Polish governments-in-exile during World War II have been preserved. Documentation for the period of the German occupation is very fragmentary, since much of

19. Janina Zaborowska, "Ustrój, dzieje i akta Kancelarii Gubernatora Warszawskiego $z$ lat 1866-1917," Archeion, 51 (1969): 148-50; Herman Rappaport, "Rewindykowane z ZSRR w r. 1964 akta Pomocnika Generał-Gubernatora Warszawskiego do spraw policyjnych z lat 1897-1917 ...,"Archeion, 50 (1968): 157-69.

20. Janina Zaborowska, "Akta Warszawskiego Sądu Okręgowego i związanych z nim innych organów sądowych," Archeion, 55 (1971): 55-65, and Herman Rappaport, "Akta prokuratora Izby Sądowej Warszawskiej z lat 1876-1917," Archeion, 56 (1971): 161-70.

21. Naczelna Dyrekcja Archiwów Państwowych, Inqeentars materiałóze archirvalnych do dziejóze rewolucji 1905-1907 r. na ziemiach polskich, vols. 1-4 (Warsaw, 1956-62). 
that material was destroyed before the German retreat, and some of it, used in the investigation of war crimes, is still kept outside the state archives. ${ }^{22}$ The central organs of the Polish People's Republic are well represented in the growing collection. However, documents for the period since 1939 are not generally available to foreigners. There are approximately 600,000 archival units in the general collection.

The Russian-language materials in the Archives of Modern Records are housed in eighteen collections consisting of 7,617 teczki or document folders on various aspects of Polish-Russian relations. For example, the pre-1939 collection entitled "The Embassy of the Polish Republic in Moscow (Ambasada Rzeczypospolitej Polskej w Moskwie)" consists of 110 folders of embassy documents on general policy, foreign relations with various countries (call numbers 2-30), conditions within the Soviet Union (31-43), cultural and educational relations (44), Polish-Russian economic and political relations (46-74), and so forth. Other substantial collections of Russian-language documents (70 folders) are found in the archival units dealing with the embassy of Poland in Kuibyshev and the Polish consulates in Kharkov and Novorossiisk. Moreover, there are 320 folders containing Russian documents among the papers of the Ministry of Foreign Affairs, 69 among those of the Ministry's Consular Department, and 28 among the papers of its press-relations and diplomatic protocol divisions. The archival units devoted to the Russian Committee in Poland and the Council of Regency contain 318 folders of Russian source material. The archival units mentioned above dealing with PolishRussian relations before 1939 comprise 834 folders of principally Russianlanguage material. ${ }^{23}$

The State Archives of the Capital City of Warsaw and of the Warsaw Province (APWiWW) house the city and provincial documents of the governmental authorities of second instance and of municipal institutions, primarily documents dating from 1795 to the present. Moreover, the Archives have jurisdiction over the regional collections of two area archives in Płock and Siedlce and of five district archives in Mława, Nowy Dwor Mazowiecki, Otwock, Piaseczno, and Żyrardów, all of which are within the Warsaw Province. The main center of the Archives, located on Krzywe Kolo Street, just within the walls of the Old Town, holds approximately 500,000 archival units -not counting the units in the seven subsections-and a library of about 12,000 volumes concerning Warsaw and Mazowsze.

22. Koberdova, "Gosudarstvennye arkhivy," pp. 153-54.

23. Barbara Maranda, a graduate student at SGPiS, assisted me in the search of the indexes and inventories at AAN. For a summary of the documents of the Polish Ministry of Foreign Affairs (1918-39), which were saved during, or replaced after, World War II see Kazimierz Wojewoda, "Zasoby Archiwalne Ministerstwa Spraw Zágranicznych z okresu 1918-1939," Archeion, 34 (1961) : 75-86. 
For the most part the Russian-language documents in the central collection of APWiWW date from 1866 to 1915 . They deal primarily with the activities of the Warsaw provincial, district, and city authorities and with the administrative bodies of notaries, mortgage offices, lower courts, schools, and police. The Warsaw collection includes 64,000 archival units which are wholly or primarily in Russian; the seven regional depositories contain 175,000 units of area and district documents in Russian. ${ }^{24}$ The easy-to-use inventories for the collection are in Polish, with transliterations of the titles of Russian sources also given in most cases. The main center of the archive also houses duplicate copies of the inventories of the area and district archives of the Warsaw province.

The official papers of the Russian University in Warsaw (1869-1917) may serve as an example of the Russian-language sources housed in APWiWW and of their classification. An outline of the contents of that collection of documents is given in volume 25 of the general inventory. ${ }^{25}$ It lists 1,116 document groups within the collection of university papers, each group designated by a separate sygnatura representing a bound folder of documents on a given topic. Each folder contains several hundred sheets. The collection of 1,116 document groups includes the minutes of the sessions of the university executive board and senate for the years 1869 through 1915 (sygnatury 1-79); the decisions of those two bodies regarding student regulations, library regulations, rules for the distribution of scholarships and stipends, syllabuses, and other academic matters (80-320); records of the meetings and activities of the four university faculties (343-520); records of the student inspection and of the disciplinary court (521-638); and so forth. Because most of those papers were removed to Russia in 1915, the cover of each folio bears, in addition to the Polish call number, the Russian fond, edinitsa khraneniia, and opis'. ${ }^{26}$ Some of this information is provided in abbreviated form in the inventory volume.

24. I am indebted to Teresa Malecka of SGPiS for assistance in arriving at these approximate figures.

25. APWiWW, Inzentarze archizvalne, vol. 25: Cesarski Uniwersytet w Warszazvic, 1869-1917 (Warsaw, 1968).

26. For example, the statute of 1869 by which the Warsaw Central School was transformed into a Russian university is to be found in Cesarski Unizeersytct w Warszawie, no. 80, "Statut z 1869 r., regulaminy wewnętrzne i instrukcje ...," sheets 2-18 (pp. 3-35). This document was earlier preserved in Gosudarstvennyi arkhiv rostovskoi oblasti, fond 527 (590), opis' 1, ed. khr. 261, sviazka 60, listy 2-18. 